Monica Tiara ${ }^{1}$

Nevi Yarni ${ }^{2}$

\section{PENDIDIKAN KARAKTER BERWAWASAN SOSIOKULTURAL DI SMA KOTA PADANG}

\begin{abstract}
Abstrak
Implementasi pendidikan karakter berwawasan sosiokultural di SMA Kota Padang. Oleh karena itu, artikel ini difokuskan dalam mengkaji pendidikan karakter berwawasan sosiokultural melalui pembelajaran Pendidikan Pancasila dan Kewarganegaraan. Metode penelitian yang digunakan adalah tipe kualitatif deskriptif dengan penentuan informan menggunakan teknik purposive sampling. Data di peroleh dari hasil observasi, wawancara, FGD (focus group discussion) dan studi dokumentasi dan kemudian dianalisis menggunakan teknik analisis data Milles dan Hubbermen. Hasil temuan menunjukkan bahwa realitas sosial sekolah khususnya ruang kelas merupakan miniatur Indonesia yang didiami oleh siswa beragam etnis dengan berbagai budaya dan kepercayaan. Kondisi ini menempatkan sekolah dan ruang kelas rentan mengalami konflik sosial antara siswa dengan siswa, siswa dengan guru serta guru dengan guru meskipun tidak sampai pada tahap konflik terbuka yang bersifat anarkis. Maka hasil temuan menunjukkan upaya untuk mencegah hal tersebut dilakukan melalui pendidikan karakter berwawasan sosiokultural melalui pembelajaran PPKn yang aktif dengan muatan budaya dan karakter bangsa. Hasil temuan juga menunjukkan bahwa pendidikan karakter berwawasan sosiokultural tidak hanya memberikan pengenalan kepada siswa terkait realitas kondisi sosiokultural Indonesia tetapi juga mengarahkan siswa untuk dapat hidup berdampingan dan mewujudkan sikap saling memahami, menghormati dan menghargai suatu perbedaan terutama menyangkut perbedaan sosiokultural.
\end{abstract}

Keywords: Pendidikan Karakter, Wawasan Sosiokultural, Pembelajaran, PPKn

\begin{abstract}
Implementation of socio-cultural character education in Padang City High School. Therefore, this article is focused on examining socio-cultural character education through learning about Pancasila and Citizenship Education. The research method used is descriptive qualitative type with the determination of informants using snowball sampling techniques. Data obtained from the results of observations, interviews, FGD (focus group discussion) and documentation studies and then analyzed using Milles and Hubbermen data analysis techniques. The findings show that the social reality of schools especially classrooms is a miniature of Indonesia which is inhabited by students of various ethnicities with various cultures and beliefs. This condition places schools and classrooms vulnerable to social conflict between students and students, students and teachers and teachers and teachers even though it does not reach the stage of anarchist open conflict. So the findings show that efforts to prevent this are done through sociocultural-oriented character education through active PPKn learning with cultural content and national character. The findings also show that sociocultural-oriented character education not only provides an introduction to students regarding the reality of Indonesian socio-cultural conditions but also directs students to be able to coexist and embody mutual understanding, respect and respect for differences, especially regarding socio-cultural differences.
\end{abstract}

Keywords : Character Education, Sociocultural Insights, Learning, Civics

${ }^{1}$ Mahasiswa Prodi Ilmu Pendidikan, Universitas Negeri Padang Alamat email monicatiara@ unp.ac.id

${ }^{2}$ Dosen/Staf Pengajar Prodi llmu Pendidikan, Universitas Negeri Padang

Jurnal Review Pendidikan dan Pengajaran (JRPP) 


\section{PENDAHULUAN}

Sebagai bangsa yang memiliki beragam etnis, ras, suku, sosial, budaya dan agama menjadikan Indonesia sebagai bangsa besar. Keberagaman tersebut menjadikan Indonesia menjadi bangsa yang memiliki nilai-nilai karakter berwawasan sosiokultural. Nilai-nilai tersebut merupakan representasi dari pola hidup yang dijalani secara turun temurun dan diwariskan melalui nilai-nilai karakter yang disepakati bersama. Maka, dalam hal ini, pengimplementasian pendidikan karakter berwawasan sosiokultural dalam Pembelajaran Pendidikan Pancasila dan Kewarganegaraan (PPKn) dirasa perlu dilakukan untuk mempersiapkan generasi cerdas dan berbudi. Hal ini ditenggarai karena pendidikan kewarganegaraan memiliki peran penting yang mengemban tugas untuk melahirkan insan yang beriman, dan bertaqwa kepada Tuhan Yang Maha Esa, Berakhlak mulia, sehat, berilmu, cakap kreatif, mandiri, dan menjadi warga Negara yang baik serta bertanggung jawab.

Undang-undang (UU) No.20, tahun 2003 tentang Sistem Pendidikan Nasional pasal 3 dinyatakan bahwa Pendidikan nasional berfungsi mengembangkan kemampuan dan membentuk watak serta peradaban bangsa yang bermartabat dalam rangka mencerdaskan kehidupan bangsa, bertujuan untuk berkembangnya potensi peserta didik agar menjadi manusia manusia yang beriman dan bertaqwa kepada Tuhan Yang Maha Esa, berakhlak mulia, sehat, berilmu, cakap, kreatif, mandiri, dan menjadi warga Negara yang demokratis serta bertanggung jawab.

Berdasarkan regulasi tersebut dapat dipahami bahwa Pendidikan nasional tidak hanya berfungsi untuk mencerdaskan kehidupan bangsa,melainkan juga untuk membentuk watak atau karakter bangsa Indonesia seperti yang di wujudkan dalam fungsi Pendidikan Pancasila dan kewarganegaraan. Hal ini dibentuk agar terwujudnya bangsa yang beradab dan bermartabat serta mampu menjadi bangsa yang unggul dan tidak kalah bersaing dengan bangsa lain.

Oleh karena itu, pendidikan tak cukup hanya untuk membuat anak pandai, tetapi juga harus mampu menciptakan nilai-nilai luhur atau karakter bangsa. Maka, penanaman nilai-nilai luhur atau karakter harus diimplementasikan dalam proses pembelajaran. Akan tetapi harapan itu belum sepenuhnya terwujud dengan maksimal. Pasalnya, pendidikan di Indonesia sampai saat ini masih dirasa kurang mampu membentuk atau membina karakter unggul generasi bangsa. Hingga hari ini, masalah moral dan karakter masih menjadi tanggungjawab yang belum terselesaikan.

Dapat dicermati media sosial, televisi, media cetak masih terus menerus menunjukkan tingginya angka kriminalitas, masalah asusila yang dilakukan masayarakat pada umumnya hingga yang dilakukan remaja berseragam sekolah. Tidak hanya itu, sesame guru, guru dan orang tua, guru dan siswa menunjukkan relasi yang tidak sehat bahkan dapat dikatan saling curiga yang berakibat pada menurunnya kualitas Pendidikan Indonesia. Hari ini, jika ada siswa yang melawan terhadap guru dianggap pejuang kemerdekaan, Jika ada guru tidak menjadi teladan dianggap hal biasa yang tidak perlu di pertentangkan

Permasalahan tersebut mengindikasikan bahwa peranan pendidikan karakter kembali menjadi solusi utama menyelesaikan masalah tersebut. Maka Pendidikan karakter seperti apa yang ideal diterapkan dalam kondisi Indonesia terkini? Hal ini masih menjadi tanda tanya besar bagi Pendidikan di Indonesia. Namun arrtikel ini mencoba memberi gambara alternatif Pendidikan karakter dengan memasukkan aspek aspek-aspek sosio-kultural (Sociocultural Values) kedalam sistem pendidikan karakter atau dalam istilah lain yaitu Sociocultural Based Character Education, terutama pada tingkat Sekolah Menengah Atas (SMA) sebagai penguatan sistem pendidikan nasional, dimana Sociocultural Based Character Education tersebut tidak dibuat dalam bentuk mata pelajaran tersendiri, tetapi dengan diintegrasikan ke dalam semua mata pelajaran yakni mata pelajaran Pendidikan Pancasila dan Kewarganegaraan (PPKn).

\section{METODE}

Penelitian ini menggunakan pendekatan kualitatif. Penelitian kualitatif merupakan penelitian yang mendeskripsikan suatu fenomena dengan bahasa dan kata-kata menggunakan metode-metode yang ilmiah (Moleong, 2014). Peneliti menggunakan teknik observasi, wawancara, FGD (focus group discussion) dan studi dokumentasi untuk mendapatkan data 
terkait implementasi pendidikan karakter berwawasan sosiokultural melalui pembelajaran PPKn. Penelitian dilakukan pada sekolah SMA multicultural di Kota Padang yakni SMA DON BOSCO, SMAN 1 Padang dan SMAN 6 Padang.

Observasi dilakukan dengan cara mengamati fakta yang terjadi di lapangan terkait implementasi pendidikan karakter berwawasan sosiokultural melalui pembelajaran PPKn dengan lembaran observasi yang sudah dipersiapkan sebelumnya. Wawancara dilakukan untuk mengetahui implementasi langsung dari informan penelitian dengan pendidikan karakter berawasan sosiokultural. Informan penelitian ditentukan melalui teknik purposive sampling dan kemudian dilakukan FGD untuk mendengarkan pendapat dan saran serta diskusi dengan berbagai tokoh seperti pihak sekolah dan praktisi pendidikan terkait permasalahan yang diteliti.

Studi dokumentasi dilakukan dengan cara mengumpulkan data-data berupa dokumen terkait pendidikan karakter berwawasan sosiokultural melalui pembelajaran Pendidikan Pancasila dan Kewarganegaraan di SMA Kota Padang, seperti RPP, sumber dan media Pembelajaran. Untuk menganalisis data yang diperoleh, peneliti berpedoman kepada teknik analisis data yang dikemukakan oleh Miles dan Hubermen yang terdiri dari tiga alur kegiatan, yakni reduksi data, penyajian data dan pengambilan kesimpulan (Ghony dan Almanshur, 2016). Keabsahan data diuji dengan triangulasi sumber, yakni mengecek data atau informasi yan diperoleh melalui sumber yang berbeda seperti membandingkan hasil pengamatan dengan wawancara atau membandingkan hasil pengamatan dengan dokumen yang sudah ada (Bachri, 2010).

\section{HASIL DAN PEMBAHASAN}

Pendidikan nasional berfungsi untuk membentuk karakter bangsa Indonesia sejalan dengan kearifan loal yang beradab dan bermartabat. Maka, dalam implementasinya Pendidikan perlu mengakomodasi segala potensi yang dimiliki peserta didik mencakup potensi sosiokultural yang ada dalam diri tiap peserta didik. Oleh karena itu, pembelajaran berjalan secara akomodatif yang mengharuskan guru memiliki pemahaman keunggulan local agar terciptanya peserta didik yang berwawasan sosiokultural.

Berpijak dari hal tersebut, pendidikan karakter berwawasan sosio-kultural menuntun siswa sebagai manusia yang mampu memahami dan menghargai dirinya dan perbedaan yang terdapat didalam lingkungannya:

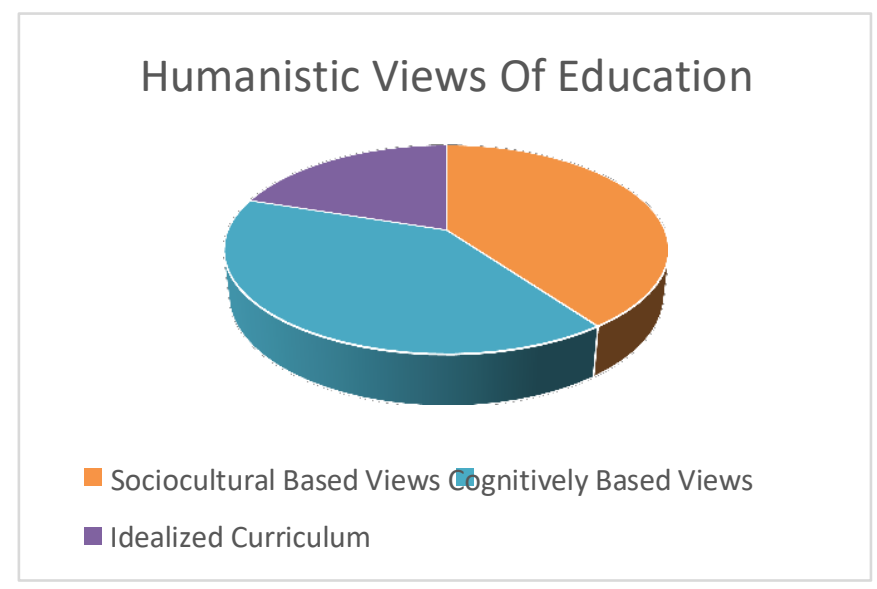

(Dubin:1986)

Diagram diatas (Larson dan Smalley: 1972) menjelaskanbagaiman sosio-kultural menjadi pedoman perilaku manusia dalam sebuah masyarakat. Dalam hal ini, wawasan sociokultural yang akan diintegrasikan pada Pendidikan karakter bertujuan untuk mengatur tingkah laku seseorang dalam kelompok, membuat seseorang sensitif terhadap status, dan membantunya 
mengetahui apa yang diharapkan orang lain terhadap dirinya dan apa yang akan terjadi jika tidak memenuhi harapan-harapan mereka.

Wawasan sosio-kultural yang menjadi focus utama pendidikan karakter dalam penelitian ini bertujuan untuk membantu peserta didik mengenali lebih jauh dirinya sebagai individu yang hidup berkelompok. Sosiokultural (sociocultural) yang dimaksud adalah gagasangagasan, kebiasaan, keterampilan, seni, dan alat yang memberi ciri pada sekelompok orang tertentu pada waktu tertentu dalam bertindak. Hal ini dikarenakan, sosio-kultural merupakan pola yang mengatur perilaku manusia.

Kenyataan bahwa tak ada masyarakat tanpa ikatan sebuah sosial-budaya. Ini menggambarkan bahwa sosiokultural untuk memenuhi kebutuhan psikologi dan biologis tertentu pada manusia. Sosiokultural menentukan, konteks tingkah laku afektif dan kognitif dan menjadi template untuk kehidupan bermasyarakat. Dengan demikian jelas bahwa sosio-kultural menjadi manifestasi perilaku yang mendarah daging dan mode dari persepsi, menjadi sangat penting dalam sebuah entitas atau kelompok tertentu.

Sosial-Kultural merupakan bagian dari instrument Pendidikan karakter. Keduanya menjadi bagain yang tak terpisahkan. Bisa diadagiumkan bahwa Pendidikan karakter adalah masakan dan garamnya adalah wawasan sosiokultural. Adagium ini menujukkan bahwa keduanya saling memiliki ketergantungan yang kuat untuk terciptanya seperti yang diungkapkan Robinson-Stuart dan Nocon (1996) yang mengumpulkan dan menyatukan beberapa perspektif pada pembelajaran karakter berwawasan sosial budaya yang dilihat dalam beberapa dekade terakhir ini.

Pada penelitian ini, pembelajaran dipandang sebagai ranah pengembangan sosiokultural peserta didik dalam artian sosio-kultural menjadi acua mengimplementasikan Pendidikan karakter seperti yang di ungkapkan Brown (2000) yakni social budaya menjadi sebuah "proses, yaitu, sebagai cara merasakan, menafsirkan, menafsirkan perasaan, berada di dunia, dan berhubungan dengan di mana seseorang berada dan dengan siapa seseorang bertemu."

Pendidikan karakter berwawasan sosial budaya adalah suatu proses pembagian makna di antara perwakilan-perwakilan kehidupan sosial budaya tertentu. Hal ini bersifat pengalaman, sebuah proses pembelajaran karakte ryang terus-menerus bertahun-tahun, dan menembus secara mendalam pada pola-pola pikir, perasaan dan tindakan seseorang. Wilhem Von Humdalk (17671835) yang mengklaim bahwa social budaya membentuk karakter seseorang.

Pendekatan yang sebenarnya menggambarkan sebagian apa yang dipresentasikan pada buku, isu, penemuan, kesimpulan, dan prinsip pembelajaran dan pengajaran karakter, prinsipnya adalah: a) Motivasi dari dalam merupakan dorongan utama untuk belajar, b) percaya diri merupakan awal yang penting untuk keberhasilan, c) karakter dan budaya merupakan suatu jalinan. Kajian tentang pendidikan karakter dalam hal ini ditujukan pada subtansi kebermaknaan atau dengan kata lain mengkaji pendidikan karakter dari sudut pandang fungsi sebagai hakikat. Berdasarkan pendekatan fungsional ini, peranan atau kebermaknaan pendidikan karakter dalam konteks sosial dan konteks budaya sangat penting dan sangat erat keberadaanya (Zagoto,dkk., 2019).

Untuk itu, materi ajar yang digunakan dalam proses pembelajaran PPKn SMA di Kota Padang seyogyanya dikembangkan melalui pendekatan fungsional dengan mengintegrasikan pendidikan karakter yang berwawasan sosial dan budaya atau dengan istilah Sociocultural Based Character Education berbasis pada kearifan dan keunggulan lokal Kota Padang ke dalam materi pelajaran yang relevan. Substansi dari proses pengembangan pembelajaran karakter dimulai dengan mengidentifikasi masalah dan kebutuhan (need analysis), dilanjutkan dengan mengembangkan bahan, dan strategi pembelajaran (model development), dan diakhiri dengan mengevaluasi efektivitas dan efisiensinya (evaluation) (Zagoto, dkk.,2018; Sarumaha, 2018; Dakhi, O., 2013).

Sebagai suatu sistem, pembelajaran karakter memiliki ciri sistem secara umum seperti halnya sistem-sistem yang lain. Sistem adalah benda, peristiwa, kejadian, atau cara yang terorganisasi yang terdiri atas bagian-bagian yang lebih kecil, dan seluruh bagian tersebut secara bersama-sama berfungsi untuk rnencapai tujuan tertentu. Setidaknya terdapat empat indikator dari sebuah sistem, yakni: 1) memiliki atau dapat dibagi menjadi bagian yang lebih kecil atau subsistem, 2) setiap bagian mempunyai fungsi sendiri-sendiri, 3) seluruh bagian itu melakukan 
fungsi secara bersama, 4) fungsi bersama tersebut mempunyai tujuan tertentu. (Hamalik, 2005). Pembelajaran karakter sebagai suatu sistem haruslah memiliki empat indikator yang dipaparkan di atas. Model umum sistem pembelajaran karakter terdiri atas komponen input, proses, dan output, bahkan dapat dilengkapi dengan outcome.

Indikator input dalam sistem pembelajaran PPKn yang mengususng misi pendidikan karakter dapat berupa siswa, mata pelajaran, metode, alat, sumber dan media pembelajaran, perangkat-perangkat pembelajaran yang lain termasuk persiapan atau perencanaan pembelajaran. Indikator proses berupa aktivitas berinteraksinya berbagai input, baik raw input (masukan siswa), instrumental input (masukan berupa alat-alat termasuk guru dan kurikulum), maupun environmental input (masukan lingkungan fisik maupun nonfisik). Hasil dari proses pembelajaran karakter yang berupa keluaran (output) merupakan indikator ketiga. Maksudnya, output merupakan cerminan langsung maupun tidak langsung dari proses pembelajaran karakter dalam pembelajaran PPKn.

Berkaitan dengan pembelajaran karakter sebagai suatu sistem, implementasi pendidikan karakter berwawasan sosiokultural melalui pembelajaran PPKn diperlukan apresiasi yang mantap dari berbagai pihak, terutama guru dan siswa yang menjadi pelaku sekaligus sasaran dalam pembelajaran karakter. Salah satu upaya tersebut direalisasikan dengan pengembangan materi ajar pendidikan karakter yang berwawasan sosiokultural (Sociocultural Based Character Education).

\section{SIMPULAN}

Pendidikan karakter berwawasan sosiokultural (Sociocultural Based Character Education) menjadi salah satu solusi alternative bagi pelaksanaan pendidikan karakter sesuai dengan kondisi wilayah sekolah dalam dalam mengantisipasi, menanggulangi, dan mencegah dekadensi moral dan karakter anak bangsa, dan hal ini juga sejalan dengan fungsi pendidikan nasional yaitu mengembangkan kemampuan dan membentuk watak serta peradaban bangsa yang bermartabat dalam rangka mencerdaskan kehidupan bangsa, dan untuk mengembangkan potensi peserta didik agar menjadi manusia manusia yang beriman dan bertaqwa kepada Tuhan Yang Maha Esa, berakhlak mulia, sehat, berilmu, cakap, kreatif, mandiri, dan menjadi warga Negara yang demokratis serta bertanggung jawab.

Selain itu juga diarahkan untuk membentuk watak atau karakter bangsa Indonesia, sehingga mampu menjadi bangsa yang beradab dan bermartabat luhur serta mampu menjadi bangsa yang memiliki keunggulan tertentu dibanding bangsa-bangsa lain. Sesuai uraian tersebut, maka keluaran institusi pendidikan atau lembaga sekolah seharusnya mampu menghasilkan orang-orang yang pandai dan baik dalam arti yang luas, dimana pendidikan untuk membuat anak pandai dan juga mampu menciptakan nilai-nilai luhur sesuai dengan karakter bangsa.

\section{DAFTAR PUSTAKA}

Aeni, A.N. (2009). "Pendidikan Nilai di SD Tanggung Jawab Seluruh Bidang Studi”. Makalah pada Konferensi Pendidikan Dasar (Kopendas) 1 Tingkat Internasional 10-11 Oktober 2009, Sumedang.

Bachri, B.S. (2010). Meyakinkan Validitas Data Melalui Triangulasi Pada Penelitian Kualitatif. Jurnal Teknologi Pendidikan, Volume 10 Nomor 1, April 2010:46-62

Charbonneau, M.P, dan Reider, B.E. 1995. The Integrated Elementary Classroom: A Developmental Model of Education for the $21^{\text {st }}$ Century.

Boston: Allyn \& BaconCondon, E. c. 1973. Introduction to Cross Cultural Communication.

New Brunswick, NJ: Rutgers University Press.Dali Gulo, (1982). Kamus Psikologi. Bandung: Tonis.

Dakhi, O. "Aplikasi Pendeteksian Kerusakan File Akibat Virus Dengan Menggunakan Metode Heuristic." Pelita Informatika Budi Darma, vol. 4, no. 1, pp. 35-41, 2013.

Dakhi, O. 2013. Belajar Javascript Dengan Mudah Dan Detail. Jakarta: Dapur Buku. pp. 1-202.

Dasim Budimansyah, (2010). Penguatan Pendidikan Karakter Kewarganegaraan untuk Membangun Karakter Bangsa. Bandung: Widya Aksara Press. 
Fogarty, R. 1991. The Mindful School: How to Integrate the Curricula. Illinois: IRI/Skylight Pub, Inc.Furqon Hidayatullah, (2010). Pendidikan Karakter: Membangun Peradaban Bangsa. Surakarta: Yuma Pustaka.

Ghony dan Almanshur. (2016). Metodologi Penelitian Kualitatif. Yogyakarta: Ar-Ruzz Media Hermawan Kertajaya, (2010). Grow with Character: The Model Marketing. Jakarta: PT.

Gramedia Pusaka Utama Kamisa, (1997). Kamus Lengkap Bahasa Indonesia. Surabaya: Kartika.

Lickona, T. (1992). Educating for Character, How Our School Can TeachRespect and Responsibility. Bantam Books, New YorkSlamet I.S.(1981). Pembinaan Watak Utama Pendidikan. Jakarta: UI Press.

Muhajir , Nandri Sugiarti. 2019. Analisis Pelaksanaan Pembelajaran PPKn dalam Pembentukan Karakter Siswa SMP Muhammadiyah 1 Makassar. Jurnal Etika Demokrasi Prodi PPKn Unismuh Makassar, 4 (1).

Moleong, L. J. (2014). Metodologi penelitian kualitatif. Bandung: Remaja Rosdakarya

Sarumaha, R., Harefa, D., \& Zagoto, Maria M. (2018). Upaya Meningkatkan Kemampuan Pemahaman Konsep Geometri Transformasi Refleksi Siswa Kelas XII-IPA-B SMA Kampus Telukdalam Melalui Model Pembelajaran Discovery Learning Berbantuan Media Kertas Milimeter. Jurnal Education and development, Vol.6 No.1, 90-96. https://doi.org/10.37081/ed.v6i1.668

Sumantri, E. (2010). Pendidikan Karakter Harapan Handal Bagi Masa Depan Pendidikan Bangsa. Kuliah Umum Prodi Pendidikan Umum SPs UPI

Suardi, S., Herdiansyah, H., Ramlan, H., \& Mutiara, I. A. (2019). Implementasi Pendidikan Karakter Melalui Mata Pelajaran Pendidikan Kewarganegaraan di SMA Jaya Negara Makassar. JED (Jurnal Etika Demokrasi), 4(1).

Suardi, S. (2018). Penerapan Model Pembelajaran Saintifik Approacd Berbasis Media Pembelajaran Kearifan Lokal pada Mata Kuliah Dasar-Dasar Sosiologi dalam Membangun Karakter dan Meningkatkan Hasil Belajar Mahasiswa Pendidikan Sosiologi Universitas Muhammadiyah Makassar. Jurnal Etika Demokrasi Prodi PPKn Unismuh Makassar, 3(2).

Zagoto, Maria M., Yarni, Nevi; Dakhi, O. (2019). Perbedaan Individu dari Gaya Belajarnya Serta Implikasinya Dalam Pembelajaran. Jurnal Review Pendidikan dan Pengajaran, 2(2), 259265.

Zagoto, Maria M. \& Dakhi, O (2018). Pengembangan Perangkat Pembelajaran Matematika Peminatan Berbasis Pendekatan Saintifik Untuk Siswa Kelas XI Sekolah Menengah Atas. Jurnal Review Pendidikan dan Pengajaran, 1(1), 157-170.

Zagoto, Maria M. (2018). Pengembangan Perangkat Pembelajaran Matematika Berbasis Realistic Mathematic Educations Untuk Siswa Kelas V Sekolah Dasar, Jurnal Education And Development, vol. 3, no. 1, p. 53, Feb. 2018. https://doi.org/10.37081/ed.v3i1.139 